University of Nebraska - Lincoln

DigitalCommons@University of Nebraska - Lincoln

Faculty Publications, Classics and Religious

Studies Department

2000

\title{
It Takes a Woman to Play a Real Man: Clara as Hero(ine) of Beaumont and Fletcher's Love's Cure
}

Anne Duncan

University of Nebraska - Lincoln, aduncan4@unl.edu

Follow this and additional works at: https://digitalcommons.unl.edu/classicsfacpub

Part of the Classics Commons

Duncan, Anne, "It Takes a Woman to Play a Real Man: Clara as Hero(ine) of Beaumont and Fletcher's Love's Cure" (2000). Faculty Publications, Classics and Religious Studies Department. 81.

https://digitalcommons.unl.edu/classicsfacpub/81

This Article is brought to you for free and open access by the Classics and Religious Studies at DigitalCommons@University of Nebraska - Lincoln. It has been accepted for inclusion in Faculty Publications, Classics and Religious Studies Department by an authorized administrator of DigitalCommons@University of Nebraska - Lincoln. 
Published in English Literary Renaissance 30:3 (2000), pp. 396-407. Copyright () 2000

English Literary Renaissance Inc. Published by Blackwell Publishing Ltd.

Used by permission. http:// www.wiley.com/bw/journal.asp?ref=0013-8312

\title{
It Takes a Woman to Play a Real Man: Clara as Hero(ine) of Beaumont and Fletcher's Love's Cure
}

\author{
Anne Duncan \\ University of Pennsylvania
}

【

PON first reading, Love's Cure seems to present a pointedly simple solution to the problem of gender ambiguity: heterosexual desire "straightens out" the cross-dressed effeminate son and virago daughter, spurring both to rediscover their "true natures." Conflicts in gender identity brought about by cross-dressing are cured by nature, in the form of desire. Thus Paula Berggren reads this play as "crude," an overly tidy resolution of "how habit, in both senses, can form personality," ${ }^{1}$ while Simon Shepherd sees Love's Cure as arguing that "custom can tell lies about a person, but ... underneath a woman is always a woman the way we assume women to be." ${ }^{2}$ This play, in fact, seems like an antitheatricalist's fantasy of closing the theaters: cross-dressing and role-playing are shut down, nature asserts her rightful place, and heterosexual marriage insures that no one will desire anything transgressive. By enacting these fantasies upon the cross-dressed sister and brother, however, the play is forced to articulate the anti-theatricalists' darkest fears: that clothing can alter as well as display one's nature. Furthermore, the figure of Clara, the "martial maid," performs both masculine and feminine roles so well that she reveals them to be roles, calling into question the tidy resolution which the play puts forward. The play's insistence on the biological grounding of femininity poses a further problem for the identity of Clara, who would have been played by a boy on the English stage.

1. Paula Berggren, " ‘A Prodigious Thing': The Jacobean Heroine in Male Disguise," Philological Quarterly 62 (1983), 394.

2. Simon Shepherd, Amazons and Warrior Women: Varieties of Feminism in Seventeenth-Century Drama (New York, 1981), p. 91. 
As Laura Levine points out, "anti-theatricalists claimed (over and over again, in many places using many citations) that costume was the 'sign' of gender, even as they betrayed the deeper and more irrational fear that costume could actually alter the gender beneath." ${ }^{3}$ The fact that the servant Bobadilla calls Lucio a "Hermaphrodite" (1.2.7) when Lucio is merely dressed in women's clothing points to anxieties about the power of clothing to change the self, anxieties most clearly articulated in the anti-theatricalists' pamphlets and sermons and in the Hic Mulier and Haec Vir pamphlets. ${ }^{4}$ Lucio's father Alvarez asks, "can strong habituall custome / Work with such Magick on the mind, and manners / In spight of sex and nature?" (2.2.140-42)..$^{5}$ As Stephen Orgel puts it, "What is our God-given essence, that it can be changed by the clothes we wear?" ${ }^{2}$ Even in this seemingly most conservative of plays about cross-dressing, the possibility of gender transgression lurks.

My analysis of Love's Cure follows Jonathan Dollimore's distinction between two kinds of transgression to be found in literary artifacts: "humanist transgression" and "transgressive reinscription." The goal of humanist transgression is to escape or transcend the social/ideological construct it opposes. It anticipates Romantic and idealistic notions of freedom and subjectivity. Modern critics often tend to view humanist transgression as the only "real" transgression; Dollimore cites as an example of this view Linda Woodbridge's disappointment with the seemingly proto-feminist rhetoric of the Hic Mulier figure. In Woodbridge's view, Hic Mulier's assertion of gender equality is undermined by the fact that she makes the assertion while dressed as a man. Unwilling to reject Hic Mulier as quickly, Dollimore argues for a valorization of "transgressive reinscription," in which transgression takes the form of inverting or reversing ideological categories. Instead of striving for "transcendence," this kind of transgression uses irony and parody to destabilize supposedly "natural" categories. Thus critics who look for humanist transgression in the gender wars of the late sixteenth and early seventeenth centu-

3. Laura Levine, Men in Women's Clothing: Anti-theatricality and effeminization 1579-1642 (Cambridge, Eng., 1994), p. 4.

4. Shepherd reads the play as "present[ing] us with the equivalents of Hic Mulier and Haec Vir" (p. 88); cf. Sandra Clark, The Plays of Beaumont and Fletcher: Sexual Themes and Dramatic Representation (New York, 1994), p. 70.

5. All quotations from Love's Cure refer to Vol. III, The Dramatic Works in the Beaumont and Fletcher Canon, general ed. Fredson Bowers, 10 vols., ed. George Walton Williams (Cambridge, Eng., 1976).

6. Stephen Orgel, Impersonations: The Performance of Gender in Shakespeare's England (Cambridge, Eng., 1996), p. 29. 
ries tend to focus on the image of the androgyne or hermaphrodite, while critics who look for transgressive reinscription tend to give more attention to the transvestite. ${ }^{7}$

To critics looking exclusively for humanist transgression, Love's Cure seems conservative, even "crude," in its exploration of gender roles. ${ }^{8}$ If we look for examples of transgressive reinscription, however, the play becomes much more complex and interesting. The cross-dressing and valorous masculine behavior of Clara, the "martial maid," constitute a kind of transgressive reinscription of masculinity as (only) performance. She is presented as the only "real man" in the play. When she "becomes" a woman, she performs equally well in that role, revealing that gender (and not just masculinity) is only a performance, and furthermore, in a reversal of English Renaissance stage practice, that a woman can perform a man best.

In making this claim, I diverge from Dollimore, whose reading of this play finds that "a relegitimation of masculinity coexists with an ironic critique of it, and a representation of masculinity's cultural unconscious." ${ }^{\prime 9}$ Dollimore replicates the play's own ideological move, shifting his investigation of gender ambiguity to an exploration of masculinity. After all, if as Dollimore argues, we do not have to privilege the conservative, recuperative ending of Haec Vir over its subversive middle section, then we can read Love's Cure as revealing that the best man of all must be played by a woman. Even though Clara would have been played by a boy actor (on the English stage, at least ${ }^{10}$ ), we do not have to privilege the actor's body as the only "real" body beneath the costume. If a transvestite theater claims that men play women better than women can, ${ }^{11}$ and if masculinity only exists in the performance of itself, then Clara proves the opposite point is true as well: a woman can play (and perhaps be) a man better

7. Jonathan Dollimore. "Subjectivity, Sexuality, and Transgression: The Jacobean Connection," Renaissance Drama 17 (1986), 53-69.

8. Cf. Clark, pp. 68-72, 156, who performs a more nuanced reading but still finds the play's message to be one of heavy-handed biological determinism.

9. Dollimore, p. 73; on the critique of masculinity, cf. Clark, pp. 70-71.

10. The Spanish play from which Love's Cure takes the idea of cross-dressed siblings could conceivably have used actresses to play the female roles, including that of Clara. The earliest elements of Love's Cure seem to have been written by Beaumont and Fletcher before Beaumont retired in 1613, and probably earlier, around 1605. It is generally thought that Philip Massinger revised the play, reworking it considerably, sometime after 1625 , and that he was heavily influenced by the Spanish play $L a$ fuerza de la costumbre, published in 1625 by Guillén de Castro y Bellris (Williams, pp. 3-11; cf. Clark, p. 171n).

11. Orgel, p. 70; Marjorie Garber, Vested Interests: Cross-Dressing \& Cultural Anxiety (New York, 1992), ch. 1. 
than any man. This inverts the hierarchy of the one-sex model ${ }^{12}$ and of English stage practice.

In her discussion of Troilus and Cressida, Laura Levine uncovers a close relationship between masculinity and performance, which, we may surmise, is at the heart of the anti-theatricalists' anxiety about cross-dressing. Masculinity and performance are connected by a kind of epistemological doubt. As a motif, "the cultivation of doubt" functions in Troilus and Cressida "as a means of producing violent rage, because in the experience of that rage men can be trusted to 'act' and perform like warriors, and thus like men. But the need for such a performance implies a much more fundamental kind of doubt ... For it implies that men are only men in the performance of their masculinity (or, put more frighteningly, that they are not men except in the performance, the constant reenactment of their masculinity) - or, and these are the implications I am particularly interested in, that they have no way of knowing they are men except in the reenactment, the relentless reenactment, of their own masculinity" (pp. 6-7).

The theme that rage enables one to prove one's masculinity (and the theme's corollary, doubt about the success of the performance) comes up repeatedly in Love's Cure, most notably in Alvarez's reactions to his son's womanish temperament. Alvarez highlights the nature of masculinity as performance when he delivers an ultimatum to his still-timorous son:

Ther's only one course left, that may redeem thee,

Which is, to strike the next man that you meet,

And if we chance to light upon a woman,

Take her away, and use her like a man,

Or I wil cut thy hamstrings. (4.3.37-41)

The connection between rage and the performance of masculinity also shows up in Vitelli's behavior toward his enemies and toward his independent-minded whore Malroda; in Lucio's eventual willingness to fight his father's enemies; and in the abortive double duel at the end of the play. The instances of this connection are too numerous to cata-

12. Thomas Laqueur, Making Sex: Body and Gender from the Greeks to Freud (Cambridge, Mass., 1990), passim., argues that the "one-sex model" of gender, in which women are seen as imperfectly developed men, was the dominant medical, religious, legal, and social paradigm until it was displaced by a "two-sex" model sometime in the eighteenth century. 
logue; I will give only a few examples. In arguing with Malroda, Vitelli becomes angry and threatens to rape her: "yeeld, and presently / Or by the inflamed blood, which thou must quench / Ile make a forcible entrie" (4.2.75-77). Trying to help her brother hold his own against the impudent servant Bobadilla, Clara both instructs and bullies him: "How? kick him Lucio: - he shall kick you Bob, / Spight o' the nose, that's flat:kick him, I say, / Or I will cut thy head off" (2.2.111-13). Alguazier picks up on Clara's use of lucking as a way for a man to assert his superior social status and says in an aside, about Malroda, "I am mad, starck mad: proud Pagan scorn her host? / I would I were but valiant enough to kick her, / Il'd wish no manhood else" (4.2.26-28). Finally, after the women try every way of pleading for peace at the double duel, the Assistente asks the bloody-minded men, "Are you men, or stone." Alvarez replies, "Men, and we'l prove it with our swords" (5.3.172-73).

In the code of masculine honor explored (and to some degree critiqued) by this play, one's masculinity must be asserted-that is, enacted - constantly against one's enemies, social inferiors, and women. It is not enough for Lucio to protest that he is a good Christian who hopes to live in peace; to count as a man in the eyes of his family as well as his enemies, he must fight to defend the family honor and to win back Genevora's "favor." Masculinity is a performance that uses, even requires, certain props: ${ }^{13}$ knives, swords, and guns, women's "favors," and of course (as Bobadilla reminds us all too often) the phallus. It is the supreme irony of the play that the best man of all, according to its own code, lacks this last (or ultimate) signifier of masculinity.

\section{III}

Clara was called "Lucio" when she was cross-dressed; she was the Lucio that should have been, Alvarez's firstborn son and a warrior nobleman. The play opens with an account of her superb performance as a man and as Alvarez's son. Lamorall relates that Alvarez came

13. Dollimore argues that masculine sexuality in this play also requires an audience of women (p. 74), as occurs most notably in the double duel at the very end. I disagree; while I think his reading of that particular scene is right, there are other moments in the play in which masculinity is performed without any "women" (except the problematic Clara) present, such as the fight between Alvarez, Sayavedra, Clara, and Vitelli in 1.3, where Eugenia, the effeminate Lucio, and the servant Bobadilla all flee the room. Masculinity seems to be just as much a performance that men put on for other men as for women. 
with his little son, grown man ${ }^{14}$

(Though 'twas said here he took a daughter with him)

To Ostends bloody siege that stage of war

Wherein the flower of many Nations acted,

And the whole Christian world spectators were;

There by his son, or were he by adoption

Or nature his, a brave Scene was presented. (1.1.37-43)

The use of a theatrical metaphor to describe the battle highlights the performative aspect not just of Clara's actions, but of all masculine action in this world. Men act in a literal "theater of war." Among those men, Clara (as "Lucio") is a star: by her valorous deeds in this battle, she wins a pardon for her father that enables them to return from exile. It is not surprising that she asks the Infanta for the pardon in a public ceremony (1.1.82-105).

R. Valerie Lucas finds it ironic that Clara is "the person who most conforms to the pattern for ideal masculinity" and that "Her function in the play is to point out men's deviations from their own chivalric code of combat and to provide an heroic example for men to emulate." ${ }^{15}$ Clara's "ideal masculinity," while ironic according to the attitudes of the play, is more than just that, for it also works to undermine those attitudes. Clara follows the code of masculine honor in both words and deeds, fighting fairly (seconding Vitelli when he is outnumbered), defending the weak (her brother), and lecturing other men (Alvarez, Vitelli) when they act less than honorably. She dares even to defy her father when she feels he transgresses the code of honor, defending Vitelli in the house of his enemies because he fights valiantly. Sayavedra exclaims, "Defend your Fathers Enemy?" and Alvarez, "Art thou mad?" Clara's rejoinder, followed by a lecture on valor and honor, is "Are you men rather?" (1.3.111-12). Significantly, Clara's act of disobedience secretly pleases her father and earns Vitelli's admiration. Alvarez says in an aside, "I am pleas'd / With what I dare not give allowance to" (1.3.137-38), and Vitelli, "Were this

14. The phrase "grown man" is worth pausing over. Clara and Lucio are cross-dressing as adults (Lucio is twenty years old, and Clara must be even older; cf. 1.3.47). instead of as the thirteen-year-old, sexually ambiguous pages of cross-dressing comedies such as Twelfth Night and As You Like It. The implication, I think, must be that "nature" has had time to develop fully, even as the custom of cross-dressing has become second nature to the siblings. The habit is thus harder to break, but the bodies are safely past the indeterminate, unstable period of puberty, ready to (re)assume their "natural" roles.

15. R. Valerie Lucas, "Hic Mulier: The Female Transvestite in Early Modern England," Renaissance and Reformation ns. 12:1 (1988), 78. 
man a friend, / How would he win me, that being my vow'd foe / Deserves so well?" (1.3.146-48). Although both men are caught up in their blood-feud, they acknowledge that Clara's conduct holds to a higher standard of honor. The same sort of situation occurs when she saves Vitelli's life a second time, after he is ambushed while visiting his whore Malroda. Clara lectures him on the expense, danger, and dishonor of keeping a whore (4.2.168-78), and he admits that she is right, even though we have heard him earlier give the standard, clichéd excuses for man's weakness of the flesh (3.3.58-65). It is true that, in this scene, Clara is no longer dressed as a man, but the lecture she gives to Vitelli far exceeds what "modesty" should allow a maiden to say. Even dressed as a woman, she is a better man than her father or Vitelli.

In contrast, when Lucio, the comic foil to Clara, finally "becomes a man" (that is, dresses as one), he is, at first, still rather gentle-Genevora's "lovely man" (4.4.17) - and then just as violent, hot-headed, and barbaric as the rest of the men in the double duel at the end of the play. While Lucio eventually becomes, in Alvarez' words, "Thy fathers true sonne" (5.3.71), Clara was a better man than either of them. The action of the plot begins when she is displaced from her position as hero, leaving a void which her brother is supposed to fill and confounding the distinction between male homosocial bonding (what Vitelli feels for her before he knows she is a woman) and heterosexual desire (what his feeling for her becomes once he knows she is a woman). ${ }^{16}$

\section{IV}

As we are reminded constantly, despite all of her valorous actions and speeches about honor, Clara is also (or "really") a woman. If masculinity exists in performance, femininity in this play seems to be grounded in biology; ${ }^{17}$ or as Bobadilla says to her, "remember Mistresse: nature hath given you a sheath onely, to signifie women are to put up mens weapons, not to draw them" (2.2.88-89). Lucio asks Clara when she will be a woman and she replies, "Would I were none. / But natures privy Seale assures me one" (2.2.139-40). When Alvarez tells her she must begin to act (and dress) like a woman, Clara replies to her father,

16. Cf. Lucas, p. 79, Dollimore, p. 77; Dollimore does not discuss Clara in this context as a man, but as a passive female spectator.

17. Laqueur; cf. note 12 above. 
Sir, I know only that

It stands not with my duty to gaine-say you,

In any thing: I must, and wd put on

What fashion you think best: though I could wish

I were what I appeare.

Alvarez answers, "Endeavour rather / To be what you are, Clara, entring here / As you were borne, a woman" (1.3.34-40). Alvarez's answer seems a particularly anti-theatrical one, countering Clara's wish that her sex would match her clothes.

Although she finds some of the "feminine" behaviors required of her as a woman difficult to perform (passivity, most notably), she conforms to other aspects of the feminine ideal. Both Bobadilla and Vitelli emphasize Clara's fiercely-guarded virginity. Bobadilla says to her in mingled admiration and resignation, "he that shall come to bestride your virginitie, had better be afoot o'er the Dragon" (2.2.100-01). Vitelli remarks: "she's yong, and faire, / And chast for sure, but with her leave the Devil / Durst not attempt her" (4.2.196-98). "Natures privy Seale" marks Clara as female, but her virginity, her perfect chastity, marks her as supremely desirable. In her very first speech Clara associates city courtiers and ladies with adulterated and unnatural gender behavior and costume, referring to them as "tissue Cavaliers" who seek a "wanton Kisse" from "painted" lips (1.3.14-17). As a man, she opposes the dress of city fops; as a woman, she assuredly will neither paint nor flirt. Unlike serving-maids with their lovers, she will not give Vitelli any "favor" except her smile, her good opinion, her self, or her sword (2.2.221, 230).

When Vitelli expresses concern that she will literally wear the pants in their future household together, Clara makes a reassuring speech to him:

Rather from this houre

I here abjure all actions of a man,

And wil esteem it happinesse from you

To suffer like a woman: love, true love

Hath made a search within me, and expel'd

All but my naturall softnesse, and made perfect

That which my parents care could not begin.

I wil show strength in nothing, but my duty,

And glad desire to please you, and in that

Grow every day more able. (4.2.184-93)

Vitelli then imagines that she will bear him a heroically strong race of sons, as her father prophesies later (5.3.190-92), even though she promises 
to be strong only in her obedience to him. She is as desirable in women's clothes as she was in men's clothes, as attractive for her old strength as she is for her newly claimed submissiveness. ${ }^{18}$ Some of her attributes her chastity, her generosity, her nobility - seem to be innate qualities of Clara's, regardless of whether she is dressed as a man or as a woman. The attributes that seem to change, on the other hand (such as her submissiveness), raise the question of performance once again.

Masculinity exists in Love's Cure only in performance. Lucio, after all, possesses a "better needle" than the one with which he sews, but Bobadilla still regards him as a "Hermaphrodite" until he acts like a man (1.2.7, 17). Femininity, on the other hand, seems to be grounded in anatomy. Yet femininity exists (only) in performance as well. This assertion seems paradoxical, given that several characters in this play define femininity as absence, or passivity, which would seem to be impossible to "perform." Clara, however, reveals that passivity is as much of a performance as action, that it too is performed upon another person, that it requires both an object and an audience. After all, she will not "suffer like a woman" without Vitelli. The only difference between the performance of femininity and the performance of masculinity is that feminine passivity must always fail against masculine action, so that masculine action will always prove to be superior, so that it will signify as masculinity.

The clearest example of the performance of femininity comes at the end of the play, when Clara attempts to halt the double duel by using the "women's weapons" - tears, sighs, prayers, her beauty - which her father promised her would be all that she would need in her new, feminine role $(1.3 .30-33 ; 5.1 .83-84,96-98)$. Rather than yielding to her properly submissive entreaties, the men ignore her and prepare to kill each other. Clara then demands her sword back from Vitelli, who reneges on his promise to return it when asked (5.3.153-64). ${ }^{19}$ Finally, Clara and Genevora threaten to engage in a duel of their own, while Eugenia threatens

18. Cf. Clark, p. 70.

19. Clara's sword is a fascinatingly overdetermined symbol: she equates it with both her virginity and her self. Her masculine self? Despite being the most obvious land of phallic symbol, it resists the simple reading of symbolic castration, because Clara reserves the right to reclaim it. Clark reads Clara's sword as "a richly symbolic gesture betokening a promise of her virginity as well as of sexual conformity," p. 70, but virginity cannot be reclaimed either, even symbolically. Despite the fact that Clara bestows the sword as a love-token, it does not function as the same land of "favor" as Genevora's glove, or as a ring, which is what Vitelli asks for. Does it represent what the play conceives as her "essential self," masculine in its strength, feminine in its association with her virginity? 
to have Bobadilla shoot her. It is this "masculine" action by the women that stops the double duel-not a threat of suicide, significantly, but a threat of murder..$^{20}$

In one sense, we can see that Clara abandons her role as heroine when she is ineffectual as a woman, and reverts to her role as hero in order to achieve her goal. We should not ignore, however, the fact that Clara arranges the women's duel beforehand by means of a note to Genevora (5.2.1-20) - hardly a "masculine" act. She performs her femininity successfully upon another woman, moving her with an entreaty; it is only with the enraged men that she fails as a woman, as a woman must. Some time after her speech about how love has perfected her natural weakness, Clara shows herself willing to assume any one of a range of gender behaviors, based on their efficacy. The play begins with an account of Clara's performance in battle, in front of an audience of all Christendom, and it ends in the theater-like space of the Castle of St. Iago, where the duels occur publicly, for all to watch. In both cases, gender exists in the performance of itself. As the anti-theatricalists feared, costume and actions are the sum total of identity.

Contemporary theorists of transvestite theaters often resorted to the assertion that men could play women better, more convincingly, than women themselves could, for the very reason that men are not women and thus can imitate them more precisely. "When actresses first appeared upon the Restoration stage in England it was said that the actor Edward Kynaston was more effective at playing female roles than any woman could be: 'Mr. Kynaston,' wrote John Downes, 'being then very young, made a compleat Female Stage Beauty, performing his Parts so well ... that it has since been disputable among the Judicious, whether any Woman that succeeded him so sensibly touch'd the Audience as he."21 This argument begs the question: according to this line of reasoning, why would men also be better at playing men? The answer which Love's Cure provides is that they would not; Clara performs the role of a man better

20. Clark, p. 71.

21. Garber is citing Downes, who wrote a history of English theater in 1708 (p. 39). I believe the attitudes Downes describes would have been common in an era of transvestite theater, such as occurred in England before the theaters were closed, and especially when the counter-example of European actresses was available. Cf. Orgel, p. 70, for English and European "evidence" of men playing women better than women could, and of both boys and women playing women. Cf. also Garber, ch. 1. 
than any man onstage. And while the character of Clara would have been played by a boy actor, this does not unambiguously support contemporary English belief in the superiority (or "naturalness") of an all-male theater, for Clara's "femininity," as a female character, would have to have been at least as "apparent" to the audience as the "masculinity" of the boy actor playing her.

To make this claim is to enter into a keenly contested debate about the experiences of English Renaissance theater audiences. One side of the debate emphasizes the "reality" of the boy actor's body beneath his female costume and points to anti-theatrical writers' concerns about theater leading to sodomy. Richmond Barbour, for example, claims that both male and female theatergoers were erotically attracted to the boy beneath the costume..$^{22}$ The other side emphasizes the "reality" of the theatrical illusion created by the female costume and often discusses contemporary concerns about theater as a kind of witchcraft. Henk Gras argues that the audience experienced "reification of character" and argues against the audience's "double consciousness" along with most other forms of metatheater. ${ }^{23}$ Both Barbour and Gras seem committed to some form of fixity: for Barbour, the actor is really a boy, and that determines how the audience responded to the character; for Gras, the character completely swallows up the actor. Neither critic is willing to allow very much flexibility to the spectator, a shifting emphasis of perception, some degree of control over a metatheatrical consciousness. While each side of the debate makes important points, they miss others. As certain other critics have

22. Richmond Barbour, "'When I Acted Young Antinous': Boy Actors and the Erotics of Jonsonian Theater," PMLA 110:4 (1995), 1006-22. On the erotics of boys playing women, cf. also Lisa Jardine, "Boy Actors, Female Roles, and Elizabethan Eroticism," from Staging the Renaissance: Reinterpretations of Elizabethan and Jacobean Drama, ed. David Scott Kastan and Peter Stallybrass (New York, 1991),pp. 57-67. Andrew Gurr, Playgoing in Shakespeare's London (New York, 1994), pp. 105-08, sees the audience as inevitably having a metatheatrical consciousness because of physical factors like uncomfortable seats and costumes reused from play to play.

23. Henk Gras, How Easy Is a Bush Suppos'd a Bear? Actor and Character in the Elizabethan Viewer's Mind (part I; cf. pp. 21-24, 25-68) and As I Am Man: Aspects of the Presentation and Audience Perception of the Elizabethan Female Page (part II; cf. pp. 57-60), European University Studies (Frankfurt am Main, 1993). Cf. also Jo E. Miller, " 'And All This Passion for a Boy?': Cross-Dressing and the Sexual Economy of Beaumont \& Fletcher's Philaster," English Literary Renaissance 27:1 (Winter 1997), 129-50, who discusses the "surprise" revelation that Bellario is a female character who has been cross-dressed throughout the play without ever speculating about the audience's ability (or inability) to assimilate this information; presumably Miller does not feel that the audience would have a constant awareness of the boy actor beneath the costume, which would then get in the way of their reimagining Bellario to have been a girl all along. 
pointed out, it is "precisely the indeterminacy of the transvestite stage" that causes this split into critical camps, a split which is based on the contradictions among contemporary sources for audience response. ${ }^{24}$

Love's Cure contains a similar kind of split: it locates the truth of identity both in the body and in performance. For this play to focus on the body of the character as providing reality, to insist that Clara is a woman because of "Natures privy seale," means that the audience would have to focus on the female character as much as on the boy actor playing her. On the other hand, for the audience to see Clara engaging in a variety of gendered behaviors, to see her as both hero and heroine, means that they must also be conscious of gender, like all acting, as performance. In order to make its anti-theatrical claim that true nature, in the form of desire, runs deeper than any temporary change wrought upon the self by costume, Love's Cure has to stage its own transgressive reinscription: it has to show a woman performing both genders supremely well.

24. Orgel, p. 31I, is quoting Ann Jones and Peter Stallybrass, "Fetishizing Gender: Constructing the Hermaphrodite in Renaissance Europe," in Body Guards: The Cultural Politics of Gender Ambiguity, ed. Julia Epstein and Kristina Straub (New York, 1991). In "Crossdressing, The Theatre, and Gender Struggle in Early Modern England," Shakespeare Quarterly 39 (1988), 422-23, and in The Stage and Social Struggle in Early Modern England (New York, 1994), p. 98, Jean E. Howard notes that a transvestite theater could be seen as natural or unnatural by contemporary sources, and stresses the "need to recognize the plurality of discourses about gender in the Renaissance." Cf. also Garber on "The Changeling Boy," pp. 84-92. 